\title{
Analyses of growth rings of Pinus merkusii from Lao P.D.R.
}

\author{
Brendan M. Buckley ${ }^{\mathrm{a}, *}$, Khwanchai Duangsathaporn ${ }^{\mathrm{b}}$, Kritsadapan Palakit ${ }^{\mathrm{b}}$, \\ Sarah Butler ${ }^{a}$, Vongphet Syhapanya ${ }^{c}$, Nakhonekham Xaybouangeun ${ }^{d}$ \\ ${ }^{a}$ Tree-Ring Laboratory, Lamont-Doherty Earth Observatory, Columbia University, 61 Route 9W, Palisades, NY 10964, USA \\ ${ }^{\mathrm{b}}$ Laboratory of Tropical Dendrochronology, Kasetsart University, Faculty of Forestry, Bangkok, Thailand \\ ${ }^{\mathrm{c}}$ National University of Laos, Faculty of Forestry, Vientiane, Lao People's Democratic Republic \\ ${ }^{\mathrm{d}}$ Research Institute of Science, Vientiane, Lao People's Democratic Republic
}

Received 13 August 2006; received in revised form 9 July 2007; accepted 10 July 2007

\begin{abstract}
We present the first tree-ring chronologies of total ring width (RW), earlywood width (EWW) and latewood width (LWW) from Lao P.D.R., from 52 core samples from 26 mature pines (Pinus merkusii Junghuhn \& De Vriese), from Phu Khao Khouay National Biodiversity Conservation Area northeast of Vientiane. The chronologies span the 262-year period from 1743 to 2005 A.D., and at least for RW and LWW exhibit strong signal strength back to the late 1700s. Correlation analyses with climate data from a composite of 13 nearby stations in Thailand indicate statistically significant $(p \leq 0.05)$ negative correlation with prior year June rainfall, and positive correlation with August-September maximum temperature. Annual radial increment is also significantly negatively correlated with percent cloud fraction, leading us to believe that growth may be adversely affected by light availability (i.e., reduced growth during periods of low light) and not positively affected by high temperature per se. Spatial correlation with sea surface temperature fields highlights the influence of the central and eastern tropical Pacific Ocean, particularly for EWW. Wavelet analysis reveals multi-decadal scale variability between 30 and 60 years for all three indices, and higher frequency power for RW and LWW between 2 and 7 years, the typical range of ENSO. While RW, EWW and LWW all appear to respond to monsoon climate, we highlight the need for far more detailed ecophysiological response studies for this species, particularly with regard to the role of light availability and temperature during the peak monsoon.
\end{abstract}

(C) 2007 Elsevier B.V. All rights reserved.

Keywords: Tree rings; Earlywood; Latewood; Pinus merkusii; Lao P.D.R.; Monsoon

\section{Introduction}

Tropical tree-ring studies have been increasingly pursued over the past decade, and with increasingly greater success (e.g., Buckley et al., 1995, 2001, 2005, 2007; D'Arrigo et al., 1994, 1997, 2006; Heinrich and Banks, 2006; Pumijumnong et al., 1995; Pumijumnong and Wanyaphet, 2006; Therrell et al., 2006; Worbes, 1999, 2002). Much of the interest is driven by the need to understand the role of the tropics in our changing global climate, where tree rings can be used as one proxy source of terrestrial climate. Increasingly too, tropical forest ecology studies have recognized the usefulness of tree rings to accurately analyze the

\footnotetext{
* Corresponding author at: Tree-Ring Laboratory, Room 108, Lamont-Doherty Earth Observatory, 61 Route 9W, Palisades, NY 10964, USA.

Tel.: +1 845365 8782; fax: +1 8453658152 .

E-mail address: bmb@ldeo.columbia.edu (B.M. Buckley).
}

temporal dynamics of tropical forest ecosystems (e.g., Ashton, 1981; Baker et al., 2005). The notion that annual growth rings are not formed in tropical trees has been convincingly refuted for many species in the neo-tropics (e.g., Brienen and Zuidema, 2006; Schongart et al., 2004; Worbes, 1999), tropical Africa (e.g., Fichtler et al., 2004; Stahle et al., 1999; Tarhule and Hughes, 2002; Therrell et al., 2006) and the Asian tropics (e.g., Berlage, 1931; Buckley et al., 1995; D'Arrigo et al., 1997; Jacoby and D'Arrigo, 1990; Pumijumnong et al., 1995).

In spite of these successes, however, tropical tree-ring research is still fraught with difficulties that arise from many sources, including unclear ring boundaries for many species in spite of environmental conditions that induce dormancy, and nebulous seasonality in some regions (for example, areas influenced by both northeast and southwest monsoon rains, such as parts of Sri Lanka and the Philippines). A dearth of baseline physiological information for the majority of tropical tree species retards our understanding of climate/tree growth linkages. 
Abundant human disturbances that range from outright clear cutting of trees to substantial injury of stems for resin collection, or the harvesting of leaves for food and building materials, makes it difficult to find suitable trees even for species with known potential (e.g., teak and pines in tropical Asia). Furthermore, political instability in many tropical countries adds an additional level of complexity to working in them. While these obstacles are daunting, increasingly successful endeavors are resulting in climate information of significant value (e.g., Buckley et al., 2005, 2007; D’Arrigo et al., 2006; Therrell et al., 2006).

\subsection{Prior tree-ring research on tropical Asian pines}

Merkus pine (Pinus merkusii Junghuhn \& De Vriese) is widespread across mainland Southeast Asia, extending from India and Myanmar, eastward to the Philippines, and southwards to northern Sumatra (Critchfield and Little, 1966). Buckley et al. (1995) successfully produced the first published tree-ring chronologies from mainland Southeast Asia, from Merkus pine and a three-leaf pine (P. kesiya Royle ex Gordon), or Khasi pine, from north central Thailand. The authors established that both species produced clear annual rings, could be crossdated to produce ring width chronologies, and could in turn be used for dendroclimatological investigation. For a detailed description of the distribution and ecology of both of Thailand's pine species see Santisuk (1997). In a follow-up study to Buckley et al. (1995), D'Arrigo et al. (1997) reported further on the use of both pines from northern Thailand for dendroclimatic research. While Khasi pine was shown to have fewer problems with crossdating, the greater age potential of Merkus pine, combined with an apparently clearer response to climate, made it a more attractive species for further study. Pumijumnong and Wanyaphet (2006) described a Merkus pine chronology from North Thailand and its response to rainfall and temperature along with a cambial activity study that implied a positive response to April and May rainfall in line with the Buckley et al. (1995) study. Buckley et al. (2005) used Merkus pine from India and Thailand to analyze relationships with global surface temperature, finding that the greatest influence on growth resided with sea surface temperature in the tropical Pacific and Indian Ocean sectors. The current study constitutes a further exploration of the response of Merkus pine to climate for an area that has not been previously studied and from where there is a virtual absence of paleoclimate information.

\subsection{The study location}

Phou Khao Khouay National Biodiversity Conservation Area (henceforth PKK) is situated about $45 \mathrm{~km}$ to the northeast

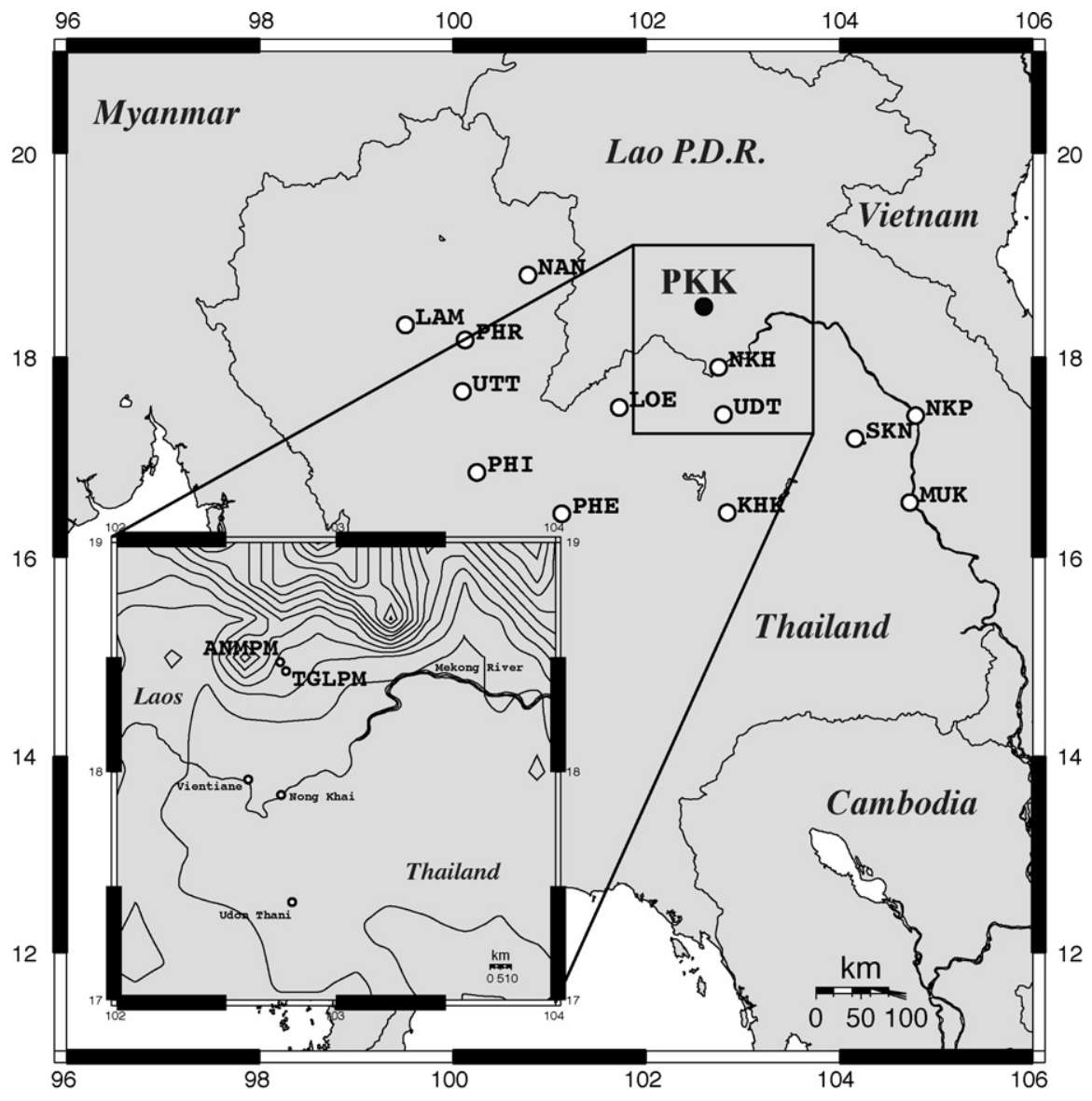

Fig. 1. Map of the study region, showing a close up of Phu Khao Khouay National Biodiversity Conservation Area and the two pine sampling regions (inset), and the location of the sampling sites (ANMPM = Ang Nam Mung Pine; TGLPM = Tad Gin Leang Pine). Also shown are the 13 meteorological stations used in this study (NAN $=$ Nan, LAM $=$ Lampang, PHR $=$ Phrae, UTT $=$ Uttaradit, PHI $=$ Phitsanulok, PHE $=$ Phetchabun, LOE $=$ Loei, NKH $=$ Nong Khai, UDT $=$ Udon Thani, KHK $=$ Khon Kaen, SKN $=$ Sakon Nakhon, NKP = Nakhon Phanom, and MUK = Mukdahan). 
of Vientiane between longitude $102^{\circ} 48^{\prime}-103^{\circ} 8^{\prime} \mathrm{E}$ and latitude $18^{\circ} 10^{\prime}-18^{\circ} 20^{\prime} \mathrm{N}$, and covers an area of 2000 square miles (Fig. 1). The dominant plant communities within PKK are best described as dry dipterocarp, mixed deciduous, mountainous pine and hill evergreen forest types. The altitude ranges from 200 to $1671 \mathrm{~m}$ above sea level. As across most of Southeast Asia, climate at PKK is dominated by the southwest monsoon from May to September, with the highest monthly rainfall totals of more than $500 \mathrm{~mm}$ found in July and August. The month of August experiences peak rainfall at nearby Nong Khai, across the border in Thailand, while maximum temperature peaks in the month of April (Fig. 2). A protracted dry season generally lasts from October to April, with cool and dry conditions from December to January, and hot and dry conditions from February to May. It is not uncommon during the dry season to have a complete absence of rainfall for several months. Maximum temperature at Nong Khai builds up to a peak in April of more than $35{ }^{\circ} \mathrm{C}$, before dropping to the minima in December of around $29{ }^{\circ} \mathrm{C}$.

The PKK contains a large lake, Ang Nam Mung, surrounded by a hilly topography with elevations up to about $1000 \mathrm{~m}$ above mean sea level (AMSL). The forests of this area are comprised of dry evergreen and mixed deciduous forest assemblages that include Merkus pine. There is no evidence of human disturbance related to stem "gouging" for the extraction of flammable wood splinters or resin, a practice common to the pine forests of Thailand. On the other hand fires appear to be common, though no data was immediately available as to the nature of the fire history and past fire intensity has not been high enough to result in deep burn scars or "cat faces" in the stems. The two sampling locations are Ang Nam Mung (ANMPM) and Taad Gin Leang (TGLPM), at 723 and $780 \mathrm{~m}$ above sea level, respectively.

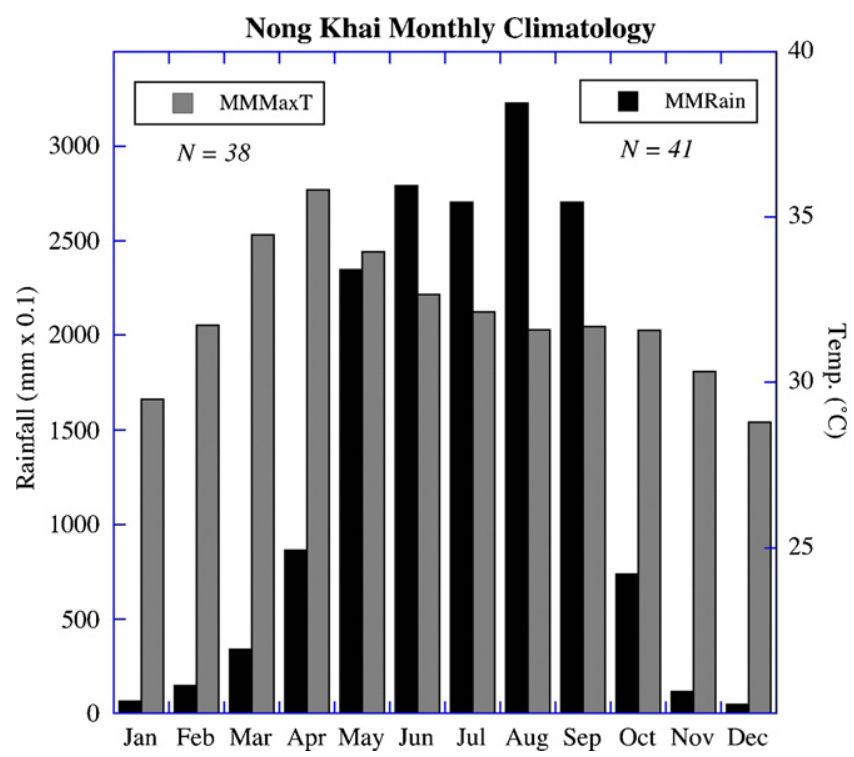

Fig. 2. Mean monthly climatology for Nong Khai, Thailand, just across the border from Vientiane, Lao P.D.R. The black bars show the precipitation means and the peak of rainfall during the month of August. The grey bars show the mean maximum temperature, which peaks in April during the height of the hot and dry season just before the onset of the monsoon.

\section{Materials and methods}

A total of 52 P. merkusii core samples were obtained from the two sites - ANMPM (30 cores from 15 trees) and TGLPM (22 cores from 11 trees) - in January 2006. The cores were taken using standard $5.15 \mathrm{~mm}$ diameter Haglof increment corers, with two cores taken from each tree, usually from opposite sides of the stems. Care was taken to avoid obvious wounds, branch scars or the uphill and downhill sides of trees, to avoid distortion of the growth rings. Back in the laboratory, standard tree-ring methodologies, as outlined in Stokes and Smiley (1968), were used for sample preparation (i.e., mounting on wooden core mounts exposing the transverse view, and surface preparation with progressively finer sandpaper).

Crossdating (e.g., Stokes and Smiley, 1968; Fritts, 1976) was challenging due to numerous false rings (Fig. 3) and occasional locally absent rings in many of the cores we analyzed. We employed several visual and computer-assisted methods of crossdating and quality control procedures that included standard programs like COFECHA (Holmes, 1983), and several customized plotting and dating programs developed at the Lamont-Doherty Earth Observatory Tree Ring Lab (LDEO-TRL). After successfully crossdating the individual time series, we measured total ring width (RW), earlywood width (EWW) and latewood width (LWW) for each series to a level of accuracy of $0.001 \mathrm{~mm}$ on a Velmex sliding stage micrometer using a beta version of the program Measure $\mathrm{J} 2 \mathrm{X}$ (http://www.voortech.com/projectj2x/) that allows for the measurement of earlywood and latewood in addition to total ring width.

We standardized our ring-width series with the widely used program ARSTAN (Cook, 1985), using a recently customized version developed by Dr. E.R. Cook and P.J. Krusic of the LDEO-TRL. For all three chronology types we selected standardization curves that adhered to either negative exponential or straight lines of horizontal or negative slope, when possible. Several cores did not fit these models, however,

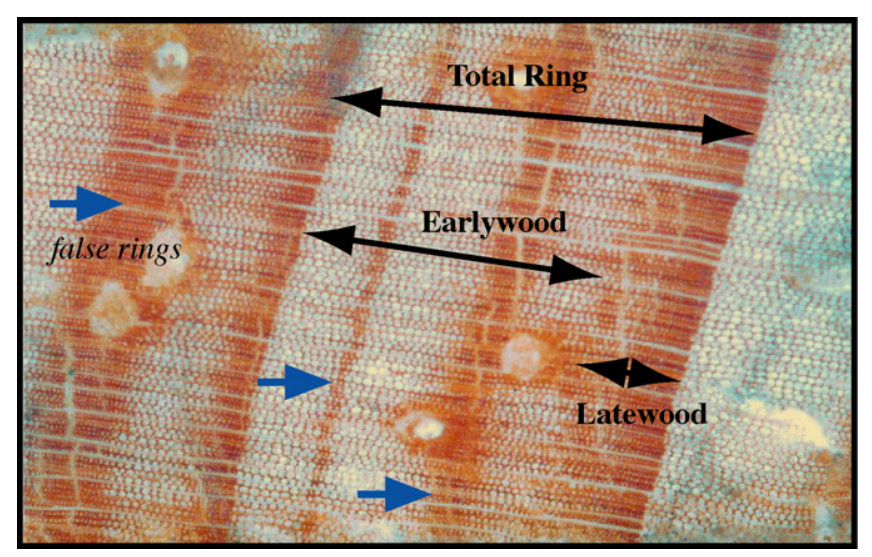

Fig. 3. Close up photograph of growth rings that exhibit false ring banding. The black arrows show the delineation between total ring width, earlywood width and latewood width. The blue arrows indicate intra-annual bands of lignified cells. In this case, two bands of such cells are included in the earlywood measurement. The direction of growth is from left to right. 
and we therefore employed cubic smoothing splines (Cook and Peters, 1981) or the Friedman super-smoother (Friedman, 1984). Both of these methods offer robust, locally data-adaptive smoothing curves that can be set to maximize the retention of low-frequency variance in the chronology indices while removing endogenous disturbances. We employed the Friedman curves with the alpha value set to 9 (least flexible), and occasionally used smoothing splines that ranged between 100 and 200 years when necessary. We also employed variance stabilization using the weighted Rbar method of Osborn et al. (1997), and we computed the mean value function using the robust bi-weight mean that discounts the effects of outliers. In addition, we used a power transformation (based on the local mean and standard deviation) for variance stabilization prior to standardization, and derived the residuals from the standardization curves, rather than the ratios, which have been shown by Cook and Peters (1997) to potentially introduce bias and exaggeration of end fitting of time series. Fig. 4 shows the finalized ARSTAN chronologies for RW, EWW and LWW with sample depth through time. For the RW and LWW chronologies EPS and Rbar statistics show sufficient signal strength back to
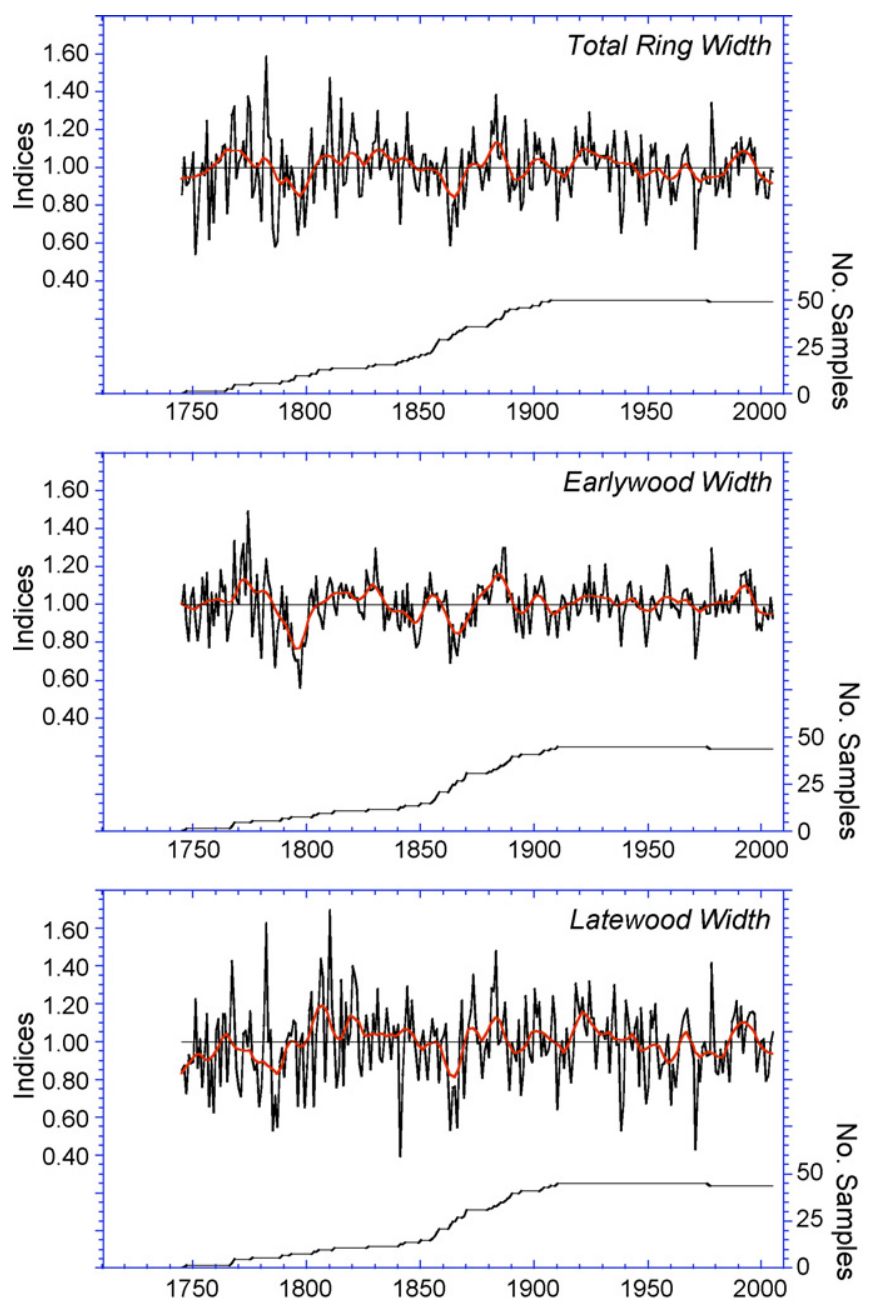

Fig. 4. Plots of (from top to bottom) total ring width, earlywood width and latewood width time series. The line at the bottom of each plot shows sample depth (number of cores) through time. the late 1700s to warrant using them for additional analyses. EWW exhibited the least agreement both within and between trees, owing to the greater variability during the juvenile growth period, and consequently had lower overall EPS and RBAR values than RW and LWW. There is a stronger relationship between LWW and RW ( $r=0.836)$ than for EWW with RW $(r=0.718)$, largely reflecting the poor agreement in the earliest part of the record.

\subsection{Earlywood and latewood width measurements}

For each ring, we measured the earlywood and latewood bands separately, in addition to measuring the total width of each ring. It is common with Merkus pine to have false latewood banding within a ring, and often the location and size of the banding is inconsistent between trees, as well as among cores from the same tree. Because the physiology of the rings is largely unknown with regards to false latewood banding, we had to make decisions on how to define the boundary between earlywood and latewood. For purposes of this study our definition of earlywood includes the tree's growth from the first tracheids to the final row of late earlywood cells, inclusive of any intra-annual bands. We define latewood as beginning with the first lignified cells of the final band of latewood and extending to the last row of cells for the year, excluding any earlywood-type cells formed near the end of the year. We show an extreme example in Fig. 3, where intra-annual banding near the end of the ring was assigned to the earlywood file. Thus defined, latewood reflects the tree's final period of lignification in preparation for dormancy during the dry season. Thus defined, earlywood reflects all other growth for that year, including intra-annual periods of lignification that are presumably the result of intra-seasonal drought, though this is not confirmed. In most instances establishing the distinction between EW and LW was fairly straightforward.

\subsection{Dendroclimatic analyses}

The nearest instrumental record to PKK is from the capital city of Vientiane, but like nearly all other stations in Laos it is missing multiple entire years of data in the period from 1975 to 1982, and many months of data in other years. The two nearest stations in Thailand, Nong Khai and Udon Thani extend back to 1968 and 1951, respectively. In order to have a more reliable data set for comparison, however, we used instrumental records from 13 nearby stations in Thailand that surround the study region (locations shown in Fig. 1) to generate mean and variance adjusted averages for monthly means of mean temperature (MeanT), minimum temperature (MinT), maximum temperature (MaxT), relative humidity $(\mathrm{RH})$, and normalized departures for total monthly rainfall (RainDep). The span of these records is from 1951 to 2005 . We obtained the daily records for all stations from the Department of Meteorology in Bangkok and generated monthly values from them for all ensuing analyses. Missing months were estimated by calculating relationships with the surrounding station data for estimation. The mean and standard deviation were calculated for each month at each station, and 
departures for each month and year were calculated and averaged across all stations to produce regional average departures for each month and year. Monthly data values were then estimated by calculating values with departures from the mean for each month at that station equal to the average departure of the other stations for the same month and year. The standard deviation for a particular month and station was then multiplied by the regional average departure for the month and year. In addition to the climate parameters noted above, we also used the KNMI Climate Explorer website (http://www.knmi.nl/) (van Oldenborgh and Burgers, 2005) to generate correlation fields with synoptic scale climate parameters, such as sea surface temperature (SST) and cloud fraction cover. Furthermore, we also applied wavelet analysis to our indices, using software from the ION Script web page for analyzing localized variations of power within a time series (http://ion.researchsystems.com/IONScript/wavelet/) (Torrence and Compo, 1998).

\section{Results}

Similar to other studies using P. merkusii from Thailand, we were able to crossdate the annual growth rings and build robust chronologies of pine growth covering the past 250 years in Laos. However, in addition to total ring width we produced EWW and LWW indices for the first time from this species. We compared all three chronology types with our 13-station (12 stations for RH) average set of climate parameters (Fig. 5). There was consistent significant $(p<0.05)$ negative correlation between all three ring parameters and June rainfall of the year prior to growth, and positive correlation with prior August MaxT. For EWW only there was an additional significant current year relationship to rainfall (negative for April and June) and MaxT (positive for March). For both RW and LWW there was additional significant positive correlation with prior September and January MaxT. For RH (not shown) only one significant correlation was found, for EWW with April of the current year. We also found significant $(p<0.05)$ correlations for all three indices with gridded sea surface temperature (SST) over the central and eastern tropical Pacific, very similar to what was found for the Thailand pines by Buckley et al. (2005), with a strong, direct response to SST in the eastern tropical Pacific and extending up to the Gulf of Alaska. This pattern is strongest in spring (MAM) as shown in Fig. 6, and is complimented by a generally symmetrical inverse response at about $30^{\circ}$ North and South, respectively. This pattern was very similar for all three indices, but strongest for EWW.

\section{Discussion}

For Merkus pine in Thailand Buckley et al. (1995) found a negative correlation with peak monsoon (September) rainfall, while Pumijumnong and Wanyaphet (2006) highlighted a soil
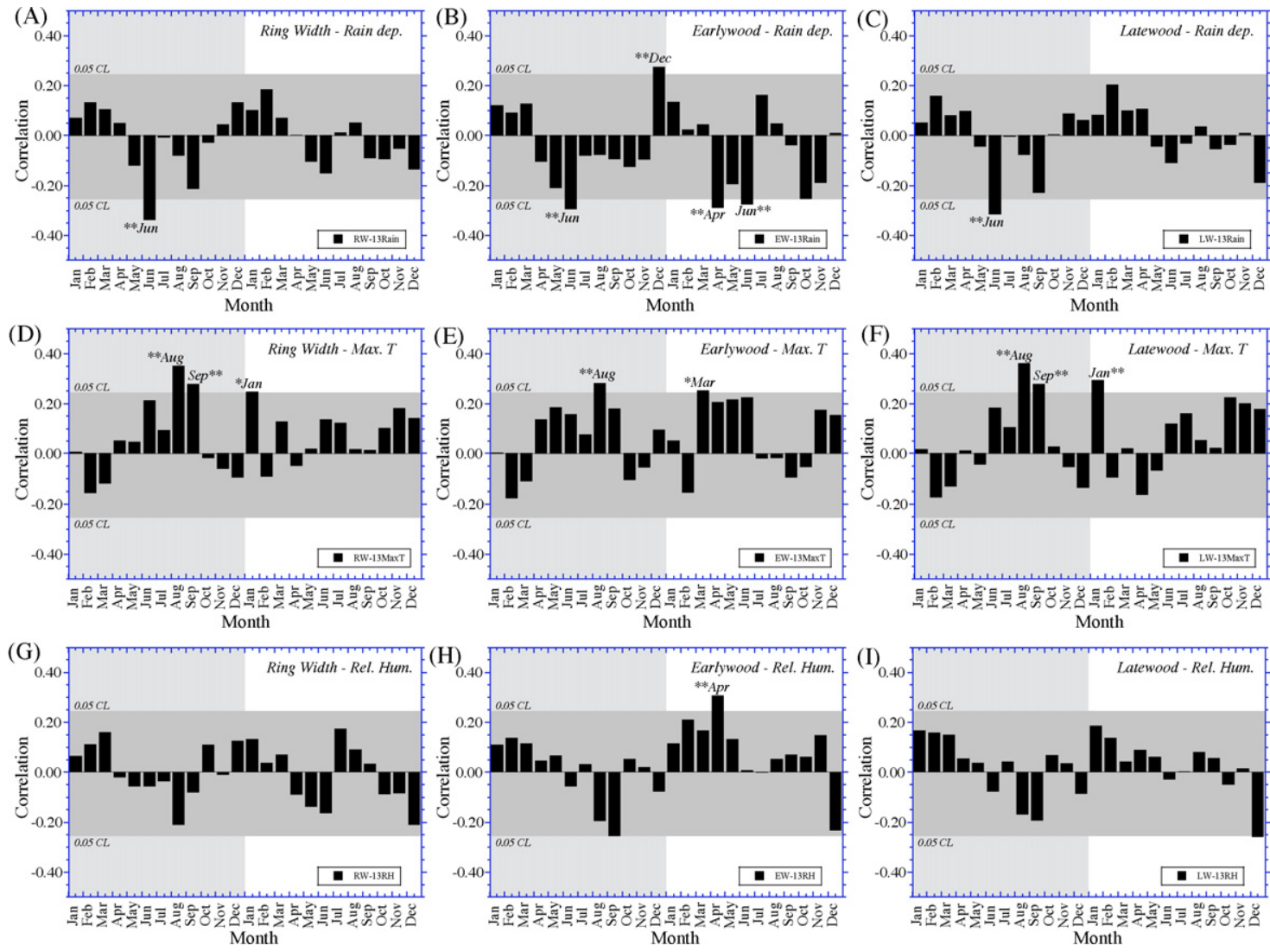

Fig. 5. Correlation plots for RW (left column), EWW (center column) and LWW (right column) with rainfall (top), and maximum temperature (bottom) progressing through a 24-month window (current year to the right, and prior year in the lighter grey-shaded area to the left). The dark grey-shaded area represents the region of non-significance (95\% level) such that bars that exit this region are statistically significant. 

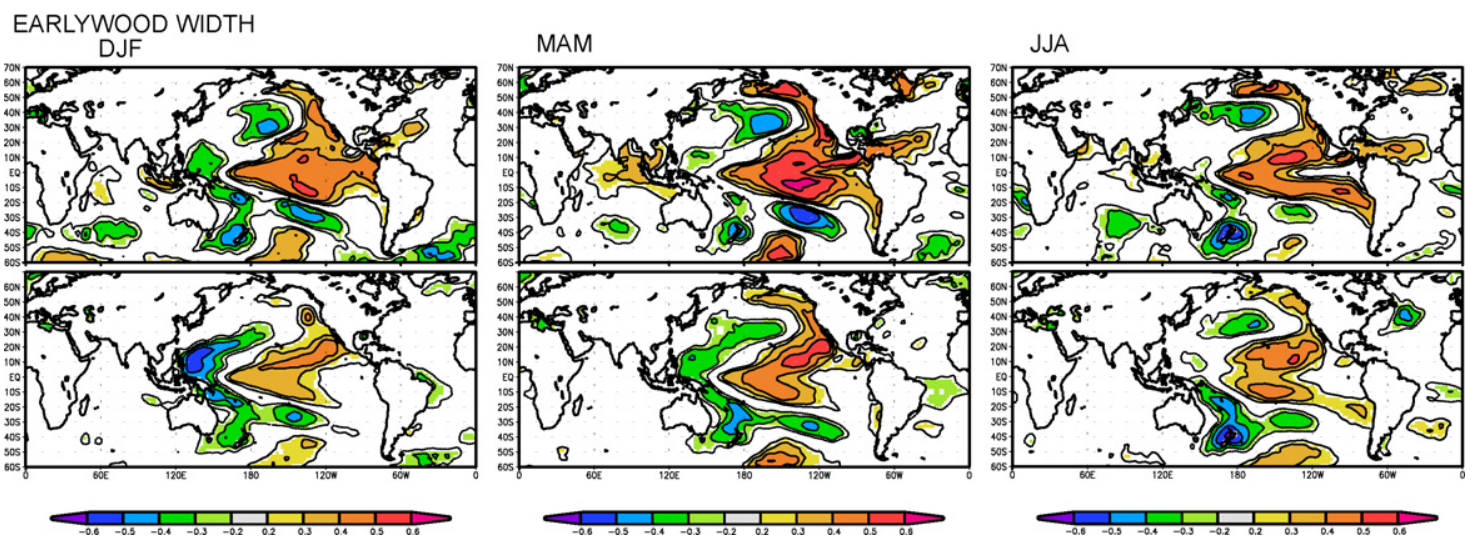

Fig. 6. Spatial Pearman correlation maps for EWW with NCDC v2 sea surface temperature for the global ocean. The top row covers the period from 1925 to 1975 , and the lower row spans from 1950 to 2005. The columns progress the season from (left) December-February prior to the year of growth, (center) March-May just before the monsoon and (right) June-August during the monsoon. Correlations for RW and LWW (not shown) reveal similar regions of significance but weaker than for EWW.

moisture response in the transitional seasons, particularly at the end of the monsoon. In this study we find a prior-year inverse correlation with June rainfall for RW, EWW and LWW. EWW showed the only current year response to rainfall, in the form of a negative correlation with April and June, but nothing for current year September. The fact that all significant correlations with rainfall are negative, with the exception of EWW with prior December, combined with positive correlations with MaxT, suggests that factors other than moisture may be limiting growth at these sites. Since MaxT in this region is correlated with reduced cloud cover and low rainfall, this may be indicative of a possible negative growth response (i.e., reduced ring width) to low light levels.

In this study the season prior to growth appears to exert some degree of pre-conditioning (Fritts, 1976) that results in wider growth rings following periods of increased PAR and narrower rings when PAR is diminished due to dense cloud cover. It is quite clear that not enough is known about the physiological response of these tropical Asian pines to climate factors such as irradiance, photoperiodicity, temperature and moisture, and more research is needed. It is plausible that much of the response we see for Merkus pine is related to light sensitivity but we just do not currently have the data for exploring this in detail. We tested the idea of light-sensitivity by comparing the EWW indices with cloud fraction cover for the period AprilJune of the year of growth, to coincide with the period of maximum inverse response to rainfall. A strong inverse correlation was found for fields over the study region, even more strongly expressed over the region from the Korean Peninsula well into adjacent mainland-China (not shown). These results are intriguing, and may perhaps lead to a better understanding of how these trees respond to the entire monsoon system, particularly with regards to the dynamics of cloud cover and light.

The statistics of our calibration with the local climate data are insufficient to allow for traditional climate reconstruction from this site, as none of the models pass the stringent calibration-verification tests commonly used in dendroclimatology (results not shown). However, the high level of withinsite crossdating statistics for Merkus pine sites from Thailand and Laos reflect uniform regional growth response that can only come from a general set of control factors that must be related to climate (Fritts, 1976). The additional information captured in the EWW and LWW also tell us that some seasonal information can be separately analyzed. However, in this study neither EWW nor LWW significantly clarify the climate response of these trees. We attribute our calibration problems at least in part to a lack of instrumental data from nearby the tree sites, in terms of both proximity and elevation, and generally poor quality of much of the available instrumental data.

Our chronologies show periods of reduced and enhanced growth throughout the past two centuries that indicate decadal scale changes in the environment. Most notable for RW are below average growth for the 1780s-1790s, the 1860s, the $1890 \mathrm{~s}$, and much of the period from the 1940 s to 1980 s. High growth periods are noted for the 1760 s to early 1780 s, much of the period from 1810 to the 1840 s, the 1880 s and the 1920 s to early 1930 s. Interpreting these in terms of the local climate might be premature, but the relationships with SST and with cloud fraction offer hope of spatial-scale reconstruction linked to larger dynamics of the monsoon system. Spatial analyses with the global SST data show a distinct pattern of correlation with SST in the global oceans, dominated by a significant positive correlation with the central equatorial Pacific and the far north Pacific, and a strong negative correlation in the Tasman Sea and in the central north Pacific. No significant relationships are revealed with SST in the Indian Ocean sector. This is the same general pattern described for this species by Buckley et al. (2005) for the SLM Merkus pine site in north central Thailand. Anomalously warm temperatures of the surface waters, such as during El Niño years, appear to be beneficial to growth through secondary linkages to climate over the tree sites. In this case, reducing the peak of convective monsoon activity during August-October may in turn increase light levels and enhance growth through increased photosynthesis. Merkus pines are well adapted to drought and fires, and as long as soil moisture is available along with adequate PAR levels, it appears that high temperature does not pose problems for cambial activity.

The presence of intra-annual ring banding in Merkus pine testifies to the species' propensity for stop-start growth through 
the active season, in order to take advantage of favorable conditions and to conserve resource when adverse conditions occur. The location and width of these bands within the annual growth ring might allow for additional information about the climate in the transition seasons, but we clearly need a better
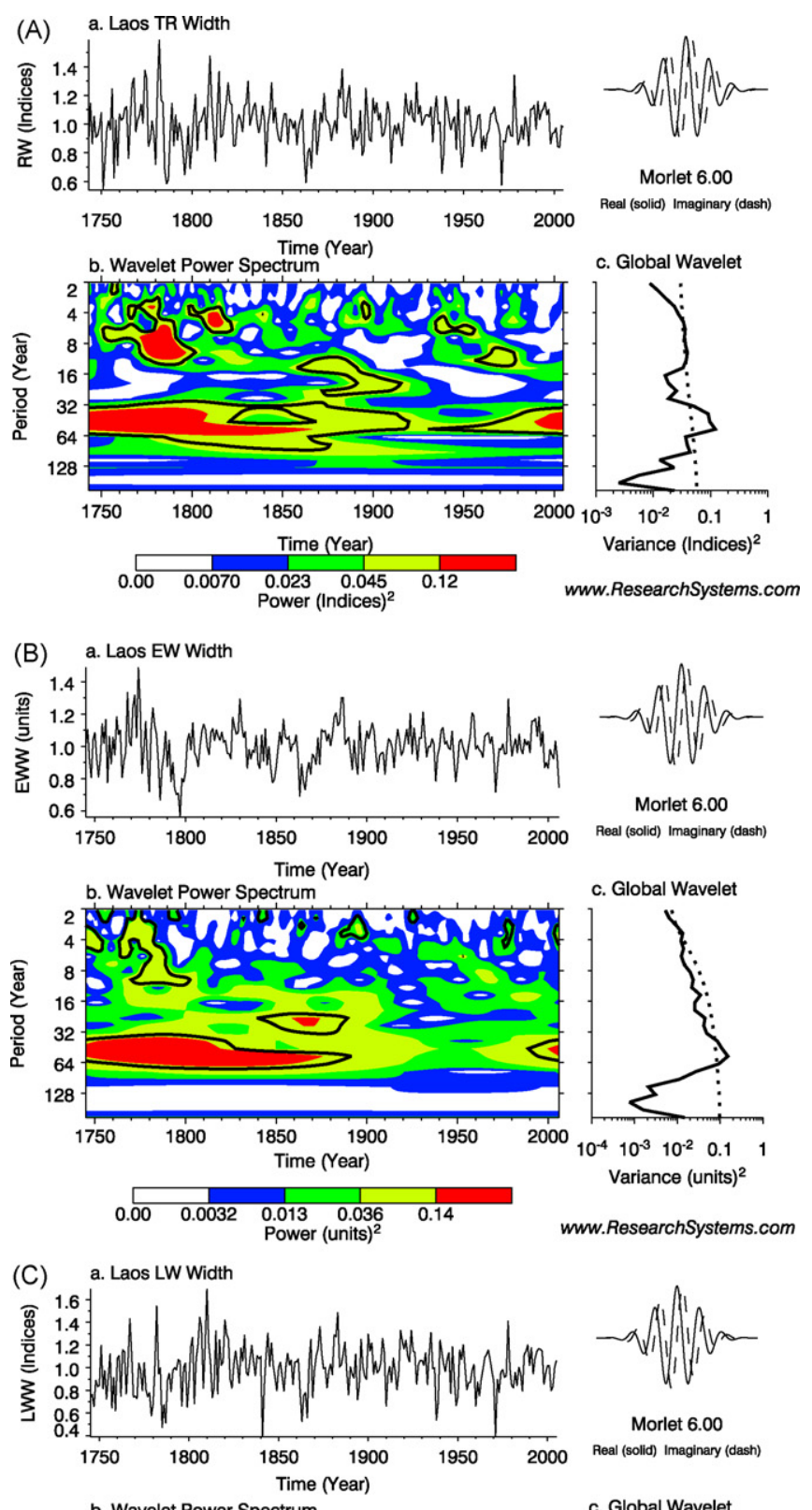

Morlet 6.00
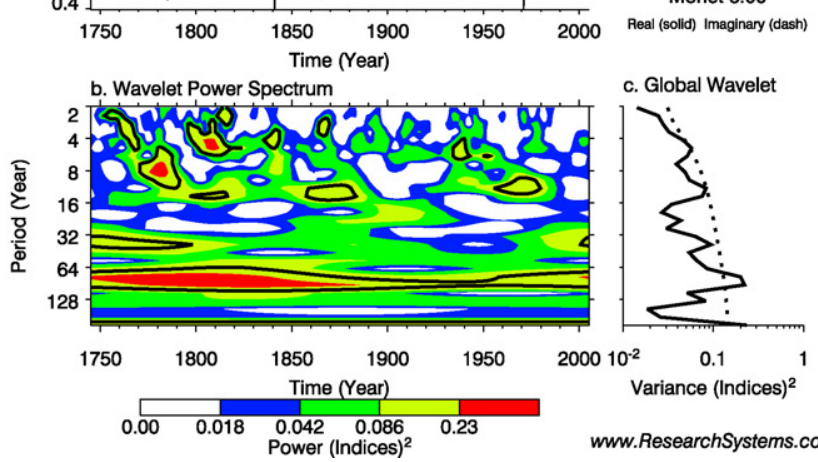

Fig. 7. Wavelet plots for (A) ring width, (B) earlywood width and (C) latewood. The red shaded areas mark regions of significant power at corresponding timescales. understanding of this species' physiology before we can interpret what these bands reflect. Our findings in this paper suggest that conventional interpretation of intra-seasonal banding as reflecting transient periods of drought-induced lignification may have to be revised if it turns out to be reflecting periods of dense cloud cover.

Wavelet analyses results for RW, EWW and LWW are shown in Fig. 7. For all three parameters multi-decadal scale variability is expressed in the range from 30 to 60 years, strongest in the early half of the record and weakening after 1850. Some degree of power is also shown in the typical ENSO bands of variability from about 2 to 7 years, for RW and LWW, strongest in the earliest portion of the record and weakening after the 1820 s.

\section{Conclusions}

The use of $P$. merkusii for dendroclimatological studies in Southeast Asia may lead to reconstruction of climate for at least the past three centuries. However, in all studies to this point the calibration with climate data is not sufficiently strong to pass certain basic tests of reconstruction fidelity, in spite of good internal agreement in the ring widths themselves that belies an overall climate control with seasonal resolution. In Laos' tropical monsoon climate, where the year is marked by alternating extremes of several months of drought followed by several months of heavy rain each year, it seems that rainfall and soil moisture availability ought be the most important factors controlling annual radial growth. However, our analyses indicate a significant response to cloud cover that needs further exploration. Hope for climate reconstruction probably lies with using synoptic-scale circulation based indices of climate, rather than local instrumental records. The strength of the relationship with SST, however, is somewhat unstable through time. Goswami et al. (2006) note a positive relationship between warm Indian Ocean SST anomalies and rainfall in central India, but during times of El Niño the region experiences drying due to subsidence, such that the aforementioned relationship is not stable. Long-term increase of daily rainfall variance is likely related to warming SST due to increase in water vapor, but this effect is dampened when the effect of El Niño is present. Recent research by Singhrattna et al. (2005) reveal an increase in the influence of ENSO over Thailand in the past two decades related to a shift in the descending arm of the Walker circulation. This time-dependent behavior may be responsible for the instability in the SST-tree-growth relationship that we see in Laos. Our wavelet analyses show time-dependent periodicity at both multi-decadal (30-60 years) and shorter timescales, the latter in the bandwidths normally associated with ENSO (around 2-7 years). More study is needed, first of all, to determine more accurately the relationship to local climate using mechanistic models and direct measurements that incorporate daily, weekly and monthly timescales. Second, combining networks of sites across the region and using principal component (PC)-based models that distill the common variance across space and time should prove more tenable for climate reconstruction. The use of earlywood and 
latewood widths, and some sort of quantification of intra-annual banding, should allow for a much more complete picture of the annual monsoon variability once the mechanisms are more clearly understood.

\section{Acknowledgements}

The authors would like to thank Dr. Souriodong Sundara, Director General of Science and Technology in Vientiane, and Dr. Suksompong Prixar, Head of Department in the Faculty of Forestry at Laos National University in Vientiane, for their assistance and support. We also wish to thank the local foresters at Phu Khao Khouay National Park for assistance in the field, and for their guidance. This research was funded by the U.S. National Science Foundation's Paleoclimate Program (grant OCE 04-02474). Lamont-Doherty Contribution No. 7066.

\section{References}

Ashton, P.S., 1981. The need for information regarding tree age and growth in tropical forests. In: Bormann, F.H., Berlyn, G.P. (Eds.), Age and Growth Rates of Tropical Trees: New Directions for Research. Bulletin Number 94. School of Forestry and Environmental Studies, Yale University, New Haven, Connecticut, USA, pp. 3-6.

Baker, P.J., Bunyavejchewin, S., Oliver, C.D., Ashton, P.S., 2005. Disturbance history and historical stand dynamics of a seasonal tropical forest in western Thailand. Ecol. Monogr. 75 (3), 317-343.

Berlage, H., 1931. On the relationship between thickness of tree rings of Djati and rainfall on Java. Tectona 24, 939-953.

Brienen, R.J.W., Zuidema, P.A., 2006. The use of tree rings in tropical forest management: projecting timber yields of four Bolivian tree species. Forest Ecol. Manage. 226, 256-267.

Buckley, B.M., Barbetti, M., Watanasak, M., D’Arrigo, R., Boonchirdchoo, S., Saratunon, S., 1995. Dendrochronological investigations in Thailand. IAWA J. 16, 393-409.

Buckley, B.M., Tongjit, O., Pumijumnong, N., Poonsri, R., 2001. Dendrometer band studies on Tectona grandis in northern Thailand. Palaeobotanist 50 (1), 83-87.

Buckley, B.M., Cook, B.I., Bhattacharyya, A., Dukpa, D., Chaudhary, V., 2005. Global surface temperature signals in pine ring-width chronologies from southern monsoon Asia. Geophys. Res. Lett. 32, L20704, doi:10.1029/ 2005GL023745.

Buckley, B.M., Palakit, K., Duangsathaporn, K., Sanguantham, P., Prasomsin, P., 2007. Decadal scale droughts over northwestern Thailand over the past 448 years: links to the tropical Pacific and Indian Ocean sectors. Clim. Dynam. 29, 63-71.

Cook, E.R., 1985. A time series analysis approach to tree ring standardization. Ph.D. Dissertation. University of Arizona, Tucson, $171 \mathrm{pp}$.

Cook, E.R., Peters, K., 1981. The smoothing spline: a new approach to standardizing forest interior tree-ring width series for dendroclimatic studies. Tree-Ring Bull. 41, 45-53.

Cook, E.R., Peters, K., 1997. Calculating unbiased tree-ring indices for the study of climate and environmental change. Holocene 7, 361-370.

Critchfield, W.B., Little, E.L., 1966. Geographic Distribution of the Pines of the World. U.S. Department of Agriculture, Washington, $97 \mathrm{pp}$.

D’Arrigo, R., Barbetti, M., Watanasak, M., Buckley, B.M., Krusic, P.J., Boonchirdchoo, S., Sarutanon, S., 1997. Progress in dendroclimatic studies of Mountain pine in Northern Thailand. IAWA J. 18 (4), 433444.

D’Arrigo, R., Jacoby, G., Krusic, P., 1994. Progress in dendroclimatic studies in Indonesia. Terrest. Atmos. Oceanogr. Sci. 5, 349-363.

D’Arrigo, R.D., Wilson, R.J., Palmer, J., Krusic, P.J., Curtis, A., Sakulich, J., Bijaksana, S., Zulaikah, S., Ngkoimani, L.O., 2006. Monsoon drought over Java, Indonesia, during the past two centuries. Geophys. Res. Lett. 33, L04709, doi:10.1029/2005GL025465.

Fichtler, E., Trouet, V., Beeckman, H., Coppin, P., Worbes, M., 2004. Climatic signals in tree rings of Burkea Africana and Pterocarpus angolensis from semiarid forests in Namibia. Trees 18, 442-451.

Friedman, J.H., 1984. A Variable Span Smoother. Department of Statistics, Stanford University, Technical Report LCS 5.

Fritts, H.C., 1976. Tree-Rings and Climate. Academic Press, London, 567 pp.

Goswami, B.N., Venugopal, V., Sengupta, D., Madhusoodanan, M.S., Xavier Prince, K., 2006. Increasing trend of extreme rain events over India in a warming environment. Science 314, 1442, doi:10.1126/science.1132027.

Heinrich, I., Banks, J.C., 2006. Tree-ring anomalies in Toona ciliata. IAWA J. 27 (2), 213-231.

Holmes, R.L., 1983. Computer-assisted quality control in tree-ring dating and measurement. Tree-Ring Bull. 43, 69-78.

Jacoby, G.C., D’Arrigo, R.D., 1990. Teak (Tectona grandis L.F.), a tropical species of large-scale dendroclimatic potential. Dendrochronologia 8, 83-98.

Osborn, T.J., Briffa, K.B., Jones, P.D., 1997. Adjusting variance for sample size in tree-ring chronologies and other regional mean timeseries. Dendrochronologia 15, 89-99.

Pumijumnong, N., Eckstein, D., Sass, U., 1995. Tree-ring research on Tectona grandis in Northern Thailand. IAWA J. 16, 385-392.

Pumijumnong, N., Wanyaphet, T., 2006. Seasonal cambial activity and tree-ring formation of Pinus merkusii and Pinus kesiya in northern Thailand in dependence on climate. Forest Ecol. Manage. 226, 279-289.

Santisuk, T., 1997. Geographical and ecological distributions of the two tropical pines, Pinus kesiya and Pinus merkusii, in Southeast Asia. Thai Forest. Bull. (Bot.) 25, 102-121

Schongart, J., Junk, W.J., Piedade, M.T.F., Ayres, J.M., Huttermann, A., Worbes, M., 2004. Teleconnection between tree growth in the Amazonian floodplains and El Nino-Southern oscillation effect. Global Change Biol. 10, 683-692.

Singhrattna, N., Rajagapolan, B., Krishna Kumar, K., Clark, M., 2005. Interannual and interdecadal variability of Thailand summer monsoon season. $\mathrm{J}$. Clim. 18, 1697-1708.

Stahle, D.W., Mushove, P.T., Cleaveland, M.K., Roig, F., Haynes, G.A., 1999. Management implications of annual rings in Pterocarpus angolensis from Zimbabwe. Forest Ecol. Manage. 124, 217-229.

Stokes, M.A., Smiley, T.L., 1968. An Introduction to Tree-Ring Dating. University of Chicago Press, Chicago, IL, 73 pp.

Tarhule, A., Hughes, M.K., 2002. Tree-ring research in semi-arid west Africa: need and potential. Tree-Ring Res. 58 (1/2), 31-46.

Therrell, M.D., Stahle, D.W., Ries, L.P., Shugart, H.H., 2006. Tree-ring reconstructed rainfall variability in Zimbabwe. Clim. Dynam. 26, 677-685.

Torrence, C., Compo, G.P., 1998. A practical guide to wavelet analysis. Bull. Am. Meteor. Soc. 79, 61-78.

van Oldenborgh, G.J., Burgers, G., 2005. Searching for decadal variations in ENSO precipitation teleconnections. Geophys. Res. Lett. 32 (15), L15701, doi:10.1029/2005GL023110.

Worbes, M., 1999. Annual growth rings, rainfall-dependent growth and longterm growth patterns of tropical trees from the Caparo Forest Reserve in Venezuela. J. Ecol. 87, 391-403.

Worbes, M., 2002. One hundred years of tree ring research in the tropics-a brief history and an outlook to future challenges. Dendrochronologia 20, 217-231. 